\title{
Juvenile Dermatomyositis with a Rare and Severe Complication: Macrophage Activation Syndrome
}

\section{Juvenil Dermatomiyozit ve Nadir ve Ciddi Komplikasyon Makrofaj Aktivasyon Sendromu}

\author{
Şerife Şebnem Önen, Zuhal Ümit, Zuhal Önder Siviş, Ferda Evin, Müşerref Kasap, \\ Burçe Emine Yaşar, Betül Sözeri \\ Ege University Faculty of Medicine, Deparment of Pediatrics, Izmir, Turkey
}

\begin{abstract}
Juvenile dermatomyositis is the most common idiopathic inflamatuary myositis in children. It is a rare, chronic, vasculopathic, autoimmune disorder characterized by symmetrical proximal muscle weakness and pathognomonic skin rash. Macrophage activation syndrome (MAS) is a severe and life theratening complication encountered in the patients of chronic rheumatic diseases of childhood. We reported a 12 year old girl presented with MAS due to juvenile dermatomyositis. She had proximal muscle weakness, heliotrope rash, high level of aldolase as spesific muscle enzyme, typical myositis findings on magnetic resonance imaging (MRI). According to the diagnostic criteria of HLH-2004 MAS was considered secondary to juvenile dermatomyositis. Fever, splenomegaly, cytopenia, hypertrigliseridemia, hemophagocytosis was present. The patient was treated with intravenous immunglobulin and metotrexate. After this treatment muscle weakness was improved day by day. On the fifteenth day of this treatment, proximal upper and lower, neck and shoulder motor extremity strength was improved dramatically. We aimed to represent treatment approach for MAS that is secondary to juvenile dermatomyositis and is a rare condition. For a patient with the diagnosis autoimmune disease, MAS should be considered when unexpected situation is encountered during course of the disease and should and treated immediately. The Journal of Pediatric Research 2014;1/4):218-21 Key Words: Macrophage activation syndrome, juvenile dermatomyositis
\end{abstract}

ÖZET

Juvenil dermatomyozit, çocukluk döneminde idiopatik inflamatuvar myozittir içinde en sık görülenidir. Proksimal kaslarda simetrik güçsüzlük ve kendine özgü döküntü ile karakterize nadir görülen, kronik, vaskülitülopatik otoimmun hastalıktır. Makrofaj aktivasyon sendromu (MAS) çocukluk dönemi kronik romatizmalı hastalarda ağır ve hayatı tehdit eden bir komplikasyondur. On iki yaşında Juvenil dermatomyozite bağlı makrofaj aktivasyon sendromu olan bir hasta sunulmuştur. Hastada proksimal kas güçsüzlüğü, heliotrop döküntü, aldolaz yüksekliği ve manyetik rezonans görüntülemede (MRG) myozit bulguları vardır. Ateş, splenomegali, sitopeni, trigliserit yüksekliği, hemafagositoz saptanan hastaya HLH-2004 MAS tanı kriterlerine göre juvenil dermatomyozit tanısı konuldu. Intravenöz imunglobulin ve metotreksat tedavisi ile kas güçsüzlüğünde giderek düzelme gözlendi. Tedavinin 15 . gününde proksimal üst ve alt ekstremite, boyun ve omuz kaslarında belirgin düzelme gözlendi. Juvenil dermatomyozit hastalığına sekonder nadir olarak görülen MAS tedavi yaklaşımımızı sunmayı amaçladık. MAS otoimun hastalı̆̆ı olan hastalarda hastalı̆̆ın seyri sırasında karşılaşılan beklenmedik bir durum gelişinde herzaman akılda tutulmalı ve hemen tedavi edilmelidir. The Journal of Pediatric Research 2014;1(4):218-21

Anahtar Kelimeler: Makrofaj aktivasyon sendromu, juvenil dermatomyozit 


\section{Introduction}

Juvenile dermatomyositis is the most common idiopathic inflamatuary myositis in children. It is a rare, chronic, vasculopathic, autoimmune disorder characterized by symmetrical proximal muscle weakness and pathognomonic skin rash (1). Genetic and envoiromental risk factors have a role in etiology of juvenil dermatomyositis (2). Incidence is 3.2 cases per million children per year in juve $\neg$ nile dermatomyositis and is more common in girls by the ratio of 2:1 (3). Prior to new treatment strategy mortality is reduced. The reported mortality rate was greater than 30 percent in the 1960s, especially when glucocorticoid has become a routine treatment agent, the rate decreased less than 2 or 3 percent in the 2000s with the advent of early combination immunosuppressive therapy (4).

Macrophage activation syndrome (MAS) is a severe and life theratening complication seen in the patients of chronic rheumatic diseases of childhood, particularly juvenile idiopathic arthritis, systemic lupus erythematosus, juvenile dermatomyositis (5). It has been considered that macrophage activation syndrome is the same disorder as the secondary hemophagocytic lymphohistiocytosis (6). Although MAS is seen chronic rheumatic disorders, few case reports have been published describing MAS in patients with juvenile dermatomyositis (7).

We report a case 12 year old girl presented with macrophage activation syndrome due to juvenile dermatomyositis.

\section{Case Report}

A 12 year old girl admitted with intermittent fever, muscle weakness, fatigue, myalgia lasting 6 months. She suffered from morning stiffness especially in shoulder muscles. On physical examination her weight was $38.5 \mathrm{~kg}$ (10-25 p), height was $157 \mathrm{~cm}$ (75-90 p), vital signs showed body temperature $38.5{ }^{\circ} \mathrm{C}$, blood pressure $110 / 70 \mathrm{mmHg}$, heart rate 85 per minute and respiratory rate 20 per minute. Eyelids and her face was erythematous called heliotrope rash. There were lots of anterior and posterior servical milimetric lymph nodules. Her liver was palpable $2 \mathrm{~cm}$ and spleen was palpable $3 \mathrm{~cm}$ below the costal margin. Traube was dull. On neurologic examination, no cranial nerve deficits were noted. Sensation was intact. Proximal upper and lower motor extremity strength was 3-4/5. Neck and shoulder muscle strength was 2-3/5. Deep tendon reflexes was observed as normoactive. Nail fold capillary patern observed as capillary dilatation, tortuosity.

Admission blood count showed a haemoglobin level of 8.4 $\mathrm{g} / \mathrm{dL}$, the mean corpuscular volume $68.8 \mathrm{fL}$, white blood cell count $6920 / \mathrm{mm}^{3}$, with $76 \%$ neutrophils, $22 \%$ lymphocytes, $2 \%$ monocytes, platelet count $144000 / \mathrm{mm}^{3}$. The serum level of C-reactive protein was $14.7 \mathrm{mg} / \mathrm{dL}$ (reference range: $0-0.8 \mathrm{mg} / \mathrm{dL}$ ), and the erythrocyte sedimentation rate exceeded $82 \mathrm{~mm}$ in $1 \mathrm{~h}$. Serum amiloide A was $683 \mathrm{mg} /$
$\mathrm{dL}$ (reference range: $<3.3 \mathrm{mg} / \mathrm{dL}$ ) Alanine aminotransferase (ALT) was $59 \mathrm{IU} / \mathrm{L}$ (reference range: 3-10 IU/L), aspartate aminotransferase (AST) $205 \mathrm{IU} / \mathrm{L}$ (reference range: 15-40 $\mathrm{IU} / \mathrm{L}$ ), alkaline phosphatase (ALP) $249 \mathrm{U} / \mathrm{L}$ (reference range: 100-350 IU/L); gama glutamil transferase was $118 \mathrm{IU} / \mathrm{L}$ (reference range: 0-38 IU/L), total protein was 7.4 (reference range: $6.4-8.3 \mathrm{gr} / \mathrm{dL}$ ) albumin was $2.6 \mathrm{mg} / \mathrm{dL}$ (reference range: 3.5-5.2 gr/dL) Lactate dehydrogenase (LDH) was $1085 \mathrm{U} / \mathrm{L}$ (reference range: 100-250 U/L), creatine kinase (CK) $25 \mathrm{IU} / \mathrm{L}$ (reference range: $34-145$ ), aldolase was $23.4 \mathrm{IU} / \mathrm{L}$ ( reference range: $1.5-6 \mathrm{IU} / \mathrm{L}$ ), Serum ferritin $14657 \mathrm{ng} / \mathrm{mL}$ (reference range: $7-140 \mathrm{ng} / \mathrm{mL}$ ). Blood lipid revealed that trigliserid was $541 \mathrm{mg} / \mathrm{dL}$ (reference range: 100-150 mg/dL), hypergamma globulinemia was present [lgG: $1800 \mathrm{mg} / \mathrm{dL}$ (875-1347), IgA: 362 (91-185), IgM: 243 (85-172)], serum complement levels were normal [C3: 170 (90-180) C4: 27.8 (10-40)], Antinuclear antibody titres (ANA) and RF was negative. Von Willabrand Factor antigene was 304\%. Bone marrow aspiration smear showed one hemaphagocytic cell and there were not atypical cell. Muscle biopsy was performed but myositis didn't show as histopathologically. Magnetic resonance imaging was used to demonstrate muscle inflammation. Magnetic T2 weighted magnetic resonance imaging of the lower extremities demonstrated high intensity areas in the muscles, indicating inflammatory muscular lesions.

Based on proximal muscle weakness, heliotrope rash, high level of aldolase as spesific muscle enzyme, typical myositis findings on MRI juvenile dermatomyositis was diagnosed. According to the diagnostic criteria of HLH-2004 MAS was considered secondary to juvenile dermatomyositis. Fever, splenomegaly, cytopenia, hypertrigliseridemia, hemophagocytosis was present.

Intravenous immunglobulin, pulse metilprednisolon, metotrexate, hydroxychloroquine were given as treatment drug. After this treatment muscle weakness was improved day by day. On the fifteenth day of this treatment, proximal upper and lower, neck and shoulder motor extremity strength was improved dramatically to 5/5 (Table I).

\section{Discussion}

Although juvenile dermatomyositis is the more common of idiopathic inflammatory myositis (1), the incidence of JDM is about 2-3 per million children per year (8). Skin rashes and proximal muscle weakness are the most common symptoms, heliotrope rash around the eyelids, erythematous rash on the extensor surfaces and proximal muscle weakness are also pathognomonic. Gastrointestinal, pulmonary, cardiac, and joint involvement can be found but is less common (9). We report a case of macrophage activation syndrome associated with juvenile dermatomyositis. In this case juvenil dermatomyositis was diagnosed from diagnostic criteria schema was first described by Bohan and Peter in 1975 (10). Diagnostic criterias are muscle weakness, elevation of muscle enzyme, abnormal EMG suggestive of inflammatory myopathy, abnormal muscle biopsy suggestive 
Önen et al.

Juvenile Dermatomyositis with a Rare and Severe Complication: Macrophage Activation Syndrome

Table I. Patients laboratory values and therapies

\begin{tabular}{|c|c|c|c|c|c|c|c|c|c|}
\hline & On admission & $1^{\text {st }}$ week & $2^{\text {nd }}$ week & $3^{\text {rd }}$ week & $4^{\text {rd }}$ week & $2^{\text {nd }}$ month & $3^{\text {rd }}$ month & $4^{\text {rd } \text { month }}$ & $5^{\text {th }}$ month \\
\hline SAA & 40 & 42,5 & 29,2 & 22 & 13,3 & 4 & 3,3 & 3,3 & 3,3 \\
\hline Aldolase & 23,4 & 22 & 10 & 9 & 8,6 & 5,3 & 3,3 & 1,3 & 0,7 \\
\hline ESR & 82 & 100 & 92 & 69 & 20 & 9 & 8 & 8 & 8 \\
\hline Ferritine & 14657 & 10000 & 9678 & 6615 & 300 & 18 & 19 & 10 & 10 \\
\hline \multicolumn{10}{|l|}{ Therapy } \\
\hline IVIG 1 gr $/ \mathrm{kg}$ & & + & & & & & & & \\
\hline PMP & & + & & + & + & & & & \\
\hline Oral steroid & & & + & + & + & & & & \\
\hline Mtx & & & + & + & + & + & + & + & + \\
\hline HOK & & & + & + & + & + & + & + & + \\
\hline
\end{tabular}

of inflammatory myopathy. At least three following criteria must be found. Symmetrical weaknesses of the proximal muscles, elevation of the serum level of one of the muscle enzymes were present in our case. Muscle biopsy performed but not shown myositis.

Affected children cannot get a diagnosis because of inability and difficulty of invasive techniques such as EMG, muscle biopsy. In recent years magnetic resonance imaging (MRI) has played an increasingly important role in the diagnosis of inflammatory muscle disease. Changes in clinical practice over time have resulted in many clinicians using noninvasive techniques, such as magnetic resonance imaging, instead of EMG and muscle biopsy. Therefore, the diagnostic criteria of Bohan and Peter modified by Children's Arthritis and Rheumatology Research Alliance (CARRA) (11). Although we couldn't demonstrate myositis as histopthologically, MRI showed myositis of the lower extremities. Our goal is to demonstrate the benefit of magnetic resonance imaging as a diagnostic modality of Juvenile Dermatomyositis (12)

Our case fulfilled the criteria of HLH-2004. Similar to classical HLH, MAS is characterized by proliferation of macrophages and T-lymphocytes MAS is a clinical and histological entity characterized by the proliferation and overactivity of macrophages with hemophagocytosis throughout the reticuloendothelial system. It is resulting in continuous fever, purpura, hepatosplenomegaly, mental status changes, prolongations in the prothrombin time and the activated partial thromboplastin time, hypofibrinogenemia, and a reduced erythrocyte sedimentation rate. Among rheumatic disorders, MAS occurs most frequently in systemic juvenile idiopathic arthritis (sJIA). In SJIA, MAS belongs to the clinical picture of disease being present in subclinical form in $30-40 \%$ of patients, whereas the overt form occurs in $10-20 \%$ (13). In addition, in recent years this syndrome has been increasingly reported in patients with juvenile systemic lupus erythematosus (SLE) (11). Still's disease and other rheumatic disorders such as Kawasaki disease is also establised in the literature (12-16).
Treatment of MAS in patients with rheumatic diseases has not been standardized yet, but it commonly includes a variety of agents such as corticosteroids, cyclosporine $A$, intravenous immunoglobulins, etoposide, cyclophosphamide, anti-TNF- $\alpha$, methotrexate, hydroxychloroquine, G-CSF (granulocyte colony-stimulating factor), and in some cases plasmapheresis. There are differences between disciplines in the choice of treatment. Corticosteroids and methotrexate are first line medications used by US pediatric rheumatologists while the European/Latin American studies show that corticosteroids are similar as US but usage of methotrexate is less (11). In our case intravenous immunglobulin, pulse metilprednisolon, metotrexate, hydroxychloroquine were given as treatment drug. After this treatment muscle weakness was improved day by day. On the fifteenth day of this treatment, proximal upper and lower, neck and shoulder motor extremity strength was improved dramatically.

Treatment should be started without delay, yet it should be kept in mind that the use of immunosuppression may further delay the diagnosis and definitive treatment. Intravenous immunglobulin and metotrexate were given the first week as treatment drug. After this treatment muscle weakness was improved day by day.

In conclusion, we want to represent that JDM is rare condition of MAS and also want to offer treatment approach. MAS should be come in mind each time patient with the diagnosis autoimmune disease. Also it should be considered when unexpected situation is encountered during course of the disease and should and treated immediately.

Conflicts of Interest: The authors reported no conflict of interest related to this article.

\section{References}

1. Dalakas MC, Hohlfeld R. Polymyositis and dermatomyositis. Lancet 2003; 362:971-82.

2. Reed AM, Ytterberg SR. Genetic and environmental risk factors for idiopathic inflammatory myopathies. Rheum Dis Clin North Am 2002; 28:891-916. 
Önen et al.

Juvenile Dermatomyositis with a Rare and Severe Complication: Macrophage Activation Syndrome

3. Symmons DP, Sills JA, Davis SM. The incidence of juvenile dermatomyositis: results from a nation-wide study. $\mathrm{Br} \mathrm{J}$ Rheumatol 1995; 34:732-6.

4. Huber A, Feldman BM. Long-term outcomes in juvenile dermatomyositis: how did we get here and where are we going? Curr Rheumatol Rep 2005; 7:441.

5. Grom AA, Mellins ED. Macrophage activation syndrome: advances towards understanding pathogenesis. Curr Opin Rheumatol 2010; 22:561.

6. Groom A. Macrophage activation syndrome and reactive hemophagocytic lymphohistiocytosis: the same entities. Curr Opin Rheumatol 2003; 15:587-90.

7. Kobayashi I, Yamada M, Kawamura N, Kobayashi R, Okano M, Kobayashi K. Platelet-specific hemophagocytosis in a patient with juvenile dermatomyositis. Acta Paediatr 2000; 89:617-9.

8. Mendez EP, Lipton R, Ramsey-Goldman R, Roettcher P, Bowyer S, Dyer A, et al. US incidence of juvenile dermatomyositis, 1995-1998: results from the National Institute of Arthritis and Musculoskeletal and Skin Diseases Registry. Arthritis Rheum 2003; 49:300-5.

9. Peter JG, Roger CA, Andrew JK. Clinical features and disease course of patients with juvenile dermatomyositis. International Journal of Rheumatic Diseases 2013; 16:5617.
10. Bohan A, Peter JB. Polymyositis and dermatomyositis (first of two parts). N Engl J Med 1975; 292:344.

11. Robinson AB, Hoeltzel MF, Wahezi DM, Becker ML, Kessler EA, Schmeling $\mathrm{H}$, et al. Clinical characteristics of children with juvenile dermatomyositis: the Childhood Arthritis and Rheumatology Research Alliance Registry. Arthritis Care Res (Hoboken) 2014; 66:404-10.

12. Tzaribachev N, Well C, Schedel J, Horger M. Whole-body MRI: a helpful diagnostic tool for juvenile dermatomyositis case report and review of the literature. Rheumatol Int 2009; 29:1511-4.

13. Behrens EM, Beukelman T, Paessler M, Cron RO. Occult macrophage activation syndrome in patients with systemic juvenile idiopathic arthritis. J Rheumatol 2007; 34:1133-8.

14. Kim JM, Kwok SK, Ju JH, Kim HY, Park SH. Reactive hemophagocytic syndrome in adult Korean patients with systemic lupus erythematosus: a case control study and literature review. J Rheumatol 2012; 39:86-93.

15. Dhote R, Simon J, Papo T, Detournay B, Sailler L. Reactive hemophagocytic syndrome in adult systemic disease: report of twenty-six cases and literature review. Arthritis Rheum 2003; 49:633-9.

16. Suresh N, Sankar J. Macrophage activation syndrome: a rare complication of incomplete Kawasaki disease. Ann Trop Paediatr 2010; 30:61-4. 